\title{
Clinical, serological and epidemiological features of hepatitis A in León, Nicaragua
}

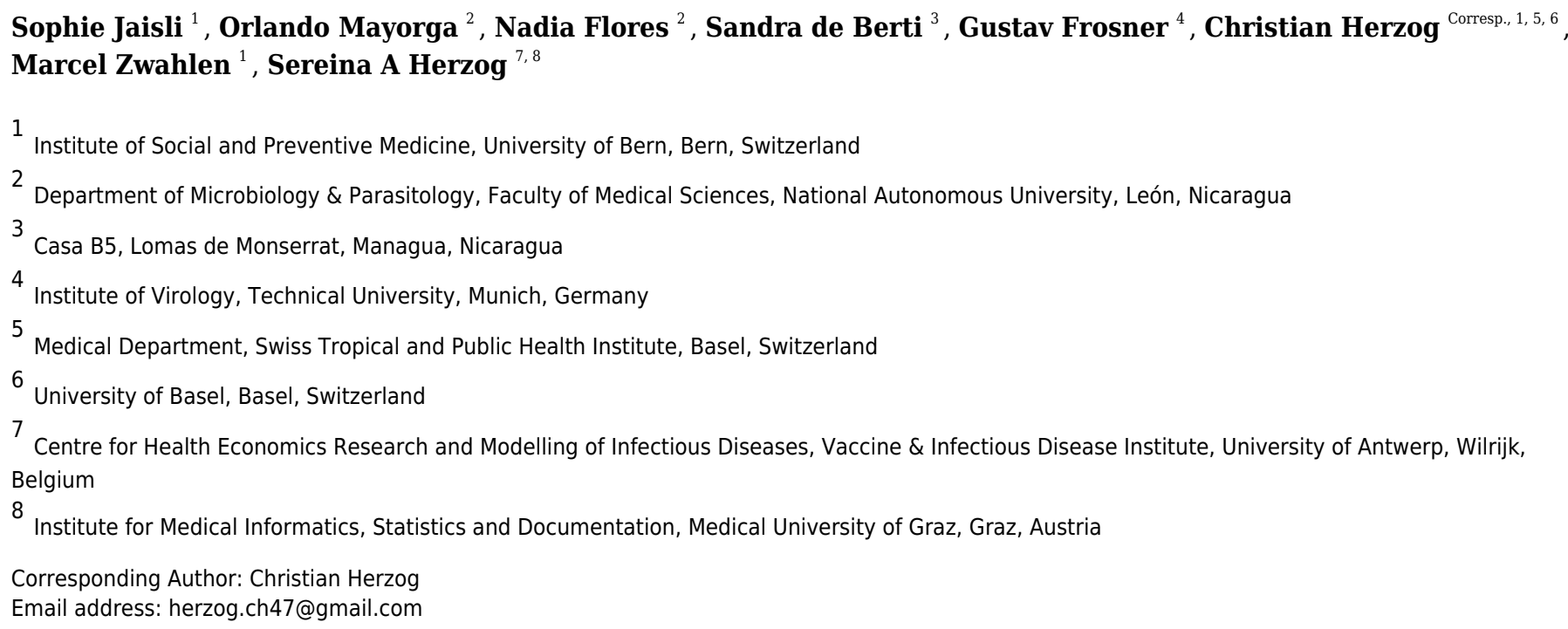

Background and Objectives: To monitor and document endemicity and disease burden of acute hepatitis $A$ in the area of an ongoing vaccine effectiveness study in León, Nicaragua. Methods: At community health centres in León, all children, adolescents and young adults presenting with jaundice and/or other clinical signs of hepatitis were offered free serologic screening (hepatitis A, B and C) and blood tests for liver enzymes and bilirubin. Clinical and socioeconomic data were collected with a structured questionnaire. Diagnosis of acute hepatitis A was confirmed by anti-HAV IgM testing. Using logistic regression we compared characteristics and living conditions of acute hepatitis A cases with those of non-cases. Results: Of 557 eligible subjects enrolled between May 2006 and March 2010, 315 (56.6\%) were diagnosed with hepatitis $A, 80.6 \%$ of them $\leq 10$ years and five $>18$ years of age. No severe cases were encountered. Apart from jaundice (95.6\%) and other signs of hepatitis $A$ (fever, pale stool, dark urine, nausea, vomiting, anorexia), two thirds of patients had moderately raised liver enzymes. Cases occurred throughout the year, with highest incidences from August to March. Poor sanitary conditions and crowding, were the main risk factors. Conclusions: In the study area, hepatitis A is still highly endemic in young and school age children living in low socioeconomic conditions. There are, however, first indications that the endemicity level is shifting from high to high-intermediate. 
2 Clinical, serological and epidemiological features of hepatitis A in León,

\section{Nicaragua}

4

5

6 Sophie Jaisli ${ }^{1}$, Orlando Mayorga ${ }^{2}$, Nadia Flores ${ }^{2}$, Sandra de Berti ${ }^{3}$, Gustav Frösner ${ }^{4}$, 7 Christian Herzog 1, 5, 6, Marcel Zwahlen ${ }^{1}$, Sereina A. Herzog 7,8

1 Institute of Social and Preventive Medicine, University of Bern, CH-3012 Bern, Switzerland

${ }^{2}$ Department of Microbiology \& Parasitology, Faculty of Medical Sciences, National

12 Autonomous University, León, Nicaragua

${ }^{3}$ Lomas de Monserrat, casa B5, Managua, Nicaragua

$14{ }^{4}$ Institute of Virology, Technical University, D-81675 Munich, Germany

${ }^{5}$ Medical Department, Swiss Tropical and Public Health Institute, CH-4051 Basel,

16 Switzerland

$17{ }^{6}$ University of Basel, CH-4001 Basel, Switzerland

$18{ }^{7}$ Centre for Health Economics Research and Modelling of Infectious Diseases, Vaccine \& Infectious Disease Institute, University of Antwerp, B-2610 Wilrijk, Belgium A-8036 Graz, Austria

22

27 Corresponding Author:

28 Christian Herzog

29 Institute of Social and Preventive Medicine, University of Bern

30 Finkenhubelweg 11, CH-3012 Bern, Switzerland

Email address: herzog.ch47@gmail.com 


\section{Abstract}

33

Background and Objectives: To monitor and document endemicity and disease burden of acute hepatitis $\mathrm{A}$ in the area of an ongoing vaccine effectiveness study in León, Nicaragua.

Methods: At community health centers in León, all children, adolescents and young adults presenting with jaundice and/or other clinical signs of hepatitis were offered free serologic screening (hepatitis A, B and C) and blood tests for liver enzymes and bilirubin. Clinical and socioeconomic data were collected with a structured questionnaire. Diagnosis of acute hepatitis A was confirmed by anti-HAV IgM testing. Using logistic regression we compared characteristics and living conditions of acute hepatitis A cases with those of non-cases. Results: Of 557 eligible subjects enrolled between May 2006 and March 2010, 315 (56.6\%) were diagnosed with hepatitis $A, 80.6 \%$ of them $\leq 10$ years and five $>18$ years of age. No severe cases were encountered. Apart from jaundice (95.6\%) and other signs of hepatitis A (fever, pale stool, dark urine, nausea, vomiting, anorexia), two thirds of patients had moderately raised liver enzymes. Cases occurred throughout the year, with highest incidences from August to March. Poor sanitary conditions and crowding, were the main risk factors.

Conclusions: In the study area, hepatitis A is still highly endemic in young and school age children living in low socioeconomic conditions. There are, however, first indications that the endemicity level is shifting from high to high-intermediate.

\section{Introduction}

The hepatitis A virus (HAV) is mainly transmitted by the fecal-oral route (WHO, 2010a).

Therefore, the burden of disease correlates with the quality of sanitary conditions, the access to clean water and the socioeconomic status (Jacobsen \& Koopman, 2005). After an incubation period of 14 to 50 days the disease might start with unspecific symptoms such as malaise, fatigue, anorexia, vomiting, abdominal discomfort and diarrhea. In the course of symptomatic illness, which ensues more often in older children and adults, in addition dark urine, pale stool and jaundice can be observed; in children below 6 years of age less than $10 \%$ show jaundice (Armstrong \& Bell, 2002). Rarely, fulminant hepatic failure develops, associated with a severe 
63 disease process and a high case fatality, usually necessitating liver transplantation (Lemon et al., 64 2018). Interestingly, HAV has been reported to be a major cause for fulminant hepatic failure in 65 children in Pakistan (Talat et al., 2020) and Latin America (Ciocca et al., 2007).

66

67 68

69 70 71

72 73 74 75 76 77 78 79 80 81

82 83 84

There are many unreported cases of hepatitis A (up to $80 \%$ of infections). WHO estimated from 1990 to 2005 an increase in the number of infections and deaths due to hepatitis A from 177 to 212 million and 30,283 to 35,245, respectively (WHO, 2010a). From the 212 million infections only 33 million cases are estimated to present as symptomatic illness (Rein et al., 2014). Different studies showed over the last two decades, however, decreasing hepatitis A seroprevalences all over the world, except for Africa, most likely due to better access to clean water, better sanitary conditions, higher educational level, and less crowded housing conditions (Jacobsen \& Wiersma, 2010). Levels of hepatitis A endemicity are defined on the basis of seroprevalence: "high ( $\geq 90 \%$ by age 10 years); intermediate $(\geq 50 \%$ by age 15 years, with $<90 \%$ by age 10 years); low ( $\geq 50 \%$ by age 30 years, with $<50 \%$ by age 15$)$; and very low ( $<50 \%$ by age 30 years)" (Jacobsen \& Wiersma, 2010). Because HAV infection leads to lifelong immunity there are in high endemic settings hardly any susceptible adults, and clinically manifest HAV infections are rare. However, if sanitary conditions improve, there will be a shift to intermediate endemicity, and with increasingly older age groups remaining susceptible, more severe cases (WHO, 2010a) and outbreaks (Bell et al., 1998) will be observed. For Nicaragua there exist very few published data on the hepatitis A epidemiology (Andani et al 2020). Hepatitis A infections are not routinely reported by the health authorities in Nicaragua, a still highly endemic country with 36.9 cases per 100,000 inhabitants reported for 2012 (OPS/PAHO, 2013).

Universal mass vaccination (UMV) of toddlers with a two-dose regimen is now recommended by WHO for countries with sizable acute hepatitis A incidences and declining endemicity (WHO, 2012). Two-dose UMV successfully eliminates hepatitis A within a few years, as shown e.g. in Israel (Levine et al., 2015). Single-dose UMV likewise lowers rapidly the disease burden, as documented for Argentina (Vizzotti et al., 2014) and Brazil (Souto, Brito \& Fontes, 2019). Although single-dose vaccination elicits in $>95 \%$ of children seroprotection for at least 7-10 years (Mayorga et al., 2016; Urueña et al., 2016; Espul et al., 2020), the long-term protective effectiveness over 20-30 years remains still to be established.

The objectives of our project were (1) to document with a prospective survey (2006 2010) - in parallel to an ongoing single-dose vaccine effectiveness study (Mayorga et al., 2016) -

Peer) reviewing PDF | (2020:12:56587:1:1:NEW 23 Mar 2021) 
94 the sustained circulation of HAV in León, Nicaragua, (2) to describe the clinical features of acute 95 hepatitis A and (3) to evaluate the HAV infection risk factors in the same study area, for which 96 already for the 1990s and the 2000s a high endemicity had been reported (Mayorga Perez et al., 97 2014).

98

99

100

101

102

103

104

105

106

107

108

109

110

111

112

113

114

115

116

117

118

119

120

121

122

123

124

\section{Materials \& Methods}

\section{Study conduct}

A viral hepatitis diagnosis survey was conducted from May 2006 to June 2010 to document - among others - the continuing circulation of HAV in the study area of a concurrent single-dose hepatitis A vaccine trial (Mayorga et al., 2016). The survey was set up by the Medical Faculty of the National Autonomous University (UNAN) in León to capture children, adolescents and adults with clinical hepatitis. During the study period regular advertisements were made in the local radio program. Everyone who presented symptoms suggestive for acute hepatitis, such as jaundice, fever, vomiting, nausea, etc. was encouraged to visit one of the community health centers in order to have his/her illness assessed for free. Reporting patients were asked if they would agree to participate in the study, which consisted - apart from answering a questionnaire - only in taking of a single blood sample $(5-7 \mathrm{ml})$. These patients were thus offered a free serologic screening to establish the viral etiology (hepatitis A, B or C), as well as free blood tests for liver enzymes and bilirubin. The presence of diagnostic anti-HAV IgM antibodies was later confirmed at the Technical University, Munich, Germany. The study was a community-based survey and no specific inclusion or exclusion criteria were applied.

The project was approved by the Medical Faculty of the UNAN, León. Written informed consent was obtained from participating patients and in case of children/adolescents from their parents or guardians.

\section{Questionnaire}

The questionnaire comprised questions on clinical features and demographic characteristics (age and sex), as well as on socioeconomic conditions like crowding (number of rooms and people per household), location of the main water source and the toilets, and some 
125 data regarding education and work. Symptoms (anorexia, nausea, vomiting, fever, malaise) and

126 clinical signs (jaundice, pale stool, dark urine) were solicited and documented. The days from

127 start of symptoms until presentation at the health centers and the history of a recent blood

128 transfusion were also noted.

129

130

131

132

133

134

135

136

137

138

139

140

141

142

143

144

145

146

147

148

149

150

151

152

153

154

155

\section{Laboratory evaluation}

Screening of serum samples for anti-HAV IgM (as for Hepatitis B and Hepatitis C) was done daily at the clinical microbiology laboratory of the Medical Faculty of UNAN León, using the enzyme immunoassay (EIA) stripe test kit ImmunoComb II from Orgenics, Israel. The sera were stored at $-20^{\circ} \mathrm{C}$ and later shipped to the Institute of Virology, Technical University, Munich, Germany, for confirmative analysis of anti-HAV IgM antibodies (CDC, 2020), using the microparticle EIA HAVAB-M 2.0 for the AxSYM system, Abbott Laboratories, USA. The following Index reference values (anti-HAV-IgM content) were used: $<0.80$ : non-reactive test, acute hepatitis A excluded; 0.80 - 1.20: gray-zone, possibly recent recovery from acute HAV infection; >1.20: reactive, indicating acute HAV infection (Frösner G., personal communication). "Gray-zone" results were counted as no hepatitis A.

Quantitative analysis of blood samples for total anti-HAV (IgG+IgM) antibodies were made at the same laboratory, using the microparticle EIA HAVAB 2.0 Quantitative for AxSYM, Abbott Laboratories, USA. A result of $\geq 20 \mathrm{mIU} / \mathrm{mL}$ was defined as seroprotective (CDC, 2020), with a lower limit of detection of $10 \mathrm{mIU} / \mathrm{mL}$.

Reference normal values for GPT were $\leq 40 \mathrm{U} / 1$ for men and $\leq 32 \mathrm{U} / 1$ for women using the GPT (ALT)-LQ test. For GOT they were $\leq 38 \mathrm{U} / 1$ for men and $\leq 31 \mathrm{U} / 1$ for women, using the GOT (AST)-LQ test. Total bilirubin values were considered normal up to $1.10 \mathrm{mg} / \mathrm{dl}$, using the BILIRUBIN T- DMSO test. All tests were from SPINREACT, S.A./S.A.U, Spain.

\section{Statistical methods}

For the descriptive analysis of categorical characteristics of acute hepatitis A cases and non-cases we calculated the chi-square statistics and p-values for the null hypothesis of difference in distribution of categories. Univariable and multivariable logistic regression analysis was used to assess associations of possible risk factors for being a hepatitis A case, such as excreta disposal, water source (yes vs no), crowding ( $>2.5$ persons per room in a given 
156 household vs $\leq 2.5$ ), age groups and sex. From the logistic regressions we report Odds Ratios and 157 95\% confidence intervals (CIs). We also calculated the geometric mean concentrations (GMCs) 158 with 95\% CIs for the total anti-HAV antibodies. For values $<10 \mathrm{mIU} / \mathrm{ml}$, a value of $5 \mathrm{mIU} / \mathrm{ml}$ 159 was used for the GMC calculation. A p-value $<0.05$ was considered as significant. Statistical 160 Software R (4.0.3) was used for the statistical analyses.

161

162

163

164

165

166

167

168

169

170

171

172

173

174

175

176

177

178

179

180

181

182

183

184

185

186

\section{Results}

\section{Study population}

A total of 575 children, adolescents and adults with suspected viral hepatitis were screened from May 2006 until June 2010. Eighteen patients had to be excluded from analysis: samples lost ( $\mathrm{n}=2)$, anti-HAV IgM serology for April-June 2010 samples lacking $(\mathrm{n}=15)$ or unclear age $(\mathrm{n}=1)$, thus leaving 557 eligible patients (see Study Flow Chart, Figure 1). Six patients had "gray-zone" results of the anti-HAV IgM test and were counted as non-hepatitis A. The majority ( $80.6 \%$ ) of the 315 patients with acute hepatitis A were children $\leq 10$ years of age, two were $\leq 1$ year and five $>18$ years old (Table 1 ). With this cohort of acute hepatitis A cases we documented the continuous exposure to HAV of the subjects enrolled into the single-dose hepatitis A vaccination trial carried out by our team in the same area during 2005 - 2012 (Mayorga et al., 2016).

We did not evaluate occupation and educational levels because the vast majority of study subjects were very young or school age children and thus an analysis of these parameters would not have made sense.

\section{Seroprevalence and antibody levels}

Quantitative anti-HAV IgG+IgM measurements could only be done in 166 of the 315 hepatitis A cases (data not shown) and in 94 of the 242 cases without hepatitis A (Table 2). All patients with acute hepatitis A had high anti-HAV antibody concentrations, with minimum and maximum levels of 1,485 mIU/ml and 181,000 mIU/ml, respectively. Eighty-three $(88.3 \%)$ of the 94 non-hepatitis A patients had protective levels of anti-HAV antibodies (min $62 \mathrm{mIU} / \mathrm{ml}$ $\max 209,900 \mathrm{mIU} / \mathrm{ml})$, representing past HAV infection. Three of the 5 children aged $\leq 1$ year 
187 had protective levels of maternal anti-HAV antibodies of 258, 341 and 6,173 mIU/ml,

188 respectively, and 2 were anti-HAV negative. The non-hepatitis A cases aged $1-\leq 6$ years, $6-\leq 11$

189 years and the $>11$ years old subjects had had hepatitis $\mathrm{A}$ in the past in $68.8 \%, 89.5 \%$ and $96.3 \%$,

190 respectively. Among the subjects $>11$ years of age only two young adults aged 18 and 19 years

191 were anti-HAV antibody negative. Only 3 and 8 of the 557 patients were screened positive (IgM

192 antibodies) for acute hepatitis B and acute hepatitis C, respectively. These cases were not further

193 investigated within this project.

194

195

Clinical features

$196 \quad$ For 15 patients the start of symptoms was unclear or missing. $56.8 \%$ of the remaining 542

197 patients presented themselves within 5 days after falling ill and one quarter after 6 to 11 days.

198 Among the 89 patients presenting later than 11 days there were proportionally less cases of

199 hepatitis A, i.e. $37.1 \%$ as compared to $62.9 \%$. The leading hepatitis A feature was jaundice. Of

200 all 557 patients with assumed viral hepatitis 495 (88.9\%) had jaundice, 301 (95.6\%) among the

201 acute hepatitis A patients and $194(80.2 \%)$ among the non-A cases $(\mathrm{p}<0.001)$ (Table 1). From the

20262 cases without jaundice only $14(22.6 \%)$ had acute hepatitis A. Hepatitis A patients had

203 significantly $(\mathrm{p}<0.001)$ more of the following solicited symptoms and signs, than non-A

204 patients: $34.3 \%$ vs. $16.1 \%$ pale stool, $61.9 \%$ vs. $33.1 \%$ dark urine, $73.7 \%$ vs. $59.5 \%$ nausea, and

$20574.3 \%$ vs. $47.5 \%$ vomiting. Rates of $79.7 \%$ vs. $70.2 \%$ were found for fever $(p=0.014)$, and

$20682.5 \%$ vs. $71.9 \%$ for anorexia $(p=0.004)$. Only the difference for malaise $(85.4 \%$ vs. $79.8 \%)$ was

207 not significant $(\mathrm{p}=0.101)$ (Table 1). Having had a blood transfusion was more often recorded in

208 subjects without hepatitis A (5.4\% vs. $1.3 \%, \mathrm{p}=0.011)$, probably a chance finding due to the

209 small numbers $(\mathrm{n}=17)$.

210

211 Laboratory findings (biochemistry)

212 Serum liver enzymes (GOT, GPT) and total serum bilirubin were all significantly (p

$213<0.001$ ) more often elevated in hepatitis A than in non-A patients (Table 1). The highest values

214 were $2920 \mathrm{U} / 1$ for GPT, $2750 \mathrm{U} / 1$ for GOT and $43.2 \mathrm{mg} / \mathrm{dl}$ for total bilirubin. According to the

215 staff of the health centers none of the study patients developed a more severe pathology later on.

216

217 Sociodemographic factors

Peer) reviewing PDF | (2020:12:56587:1:1:NEW 23 Mar 2021) 
218

219

220

221

222

223

224

225

226

227

228

229

230

231

232

233

234

235

236

237

238

239

240

241

242

243

244

245

246

247

248

4

The odd ratio (OR) for contracting hepatitis A was for children aged $5-\leq 10$ years 2.49 (crude) and 2.45 (adjusted), respectively, and then declined with age to 0.06 (crude) and 0.06 (adjusted), respectively, in the patients aged $>18$ years (Table 3 ). Logistic regression did not change these values for the age groups, the p-value stayed significant with $<0.001$. Significantly less cases of acute hepatitis A were found in children from $>10$ years onwards. This fact was independent from other sociodemographic factors. The OR for having a toilet inside the house was 0.7 (crude) and 0.75 (adjusted), respectively, with p-values of 0.036 (crude) and 0.191 (adjusted), respectively, however, no longer significant after logistic regression. The place of the toilet was a factor probably influenced by other hygiene conditions and/or sex and age and was thus not an independent risk factor. OR for 'crowding' was 1.56 (crude) and 1.1 (adjusted), with p-values of 0.01 (crude) and 0.62 (adjusted), respectively; thus, also crowding was not found to be an independent risk factor (Table 3). Logistic regression analyses were also made for the combinations of age groups and crowding, age groups and water source, localization of toilet and sex, and again no significant findings were seen and no differences could be observed (data not shown).

\section{Seasonality}

All along the observation period May 2006 to June 2010 cases of suspected viral hepatitis were enrolled ( 11.1/month), with slightly more patients presenting themselves at the health centers in the 1 st and 3rd quarters of the year (data not shown). 56.6\% of suspected cases were diagnosed with acute hepatitis A ( 6.7/month). On average, more cases of acute hepatitis A were diagnosed in the 4 th and 1st quarters (autumn \& winter) than in the 2nd and 3rd quarters (Figure 2). The percentage of hepatitis A cases among all persons examined decreased from $63.5 \%$ $(n=54 / 139)$ in 2006 to $50.0 \%(n=32 / 96)$ cases in $2010(p=0.013$, $p$ for trend=0.0016). The age distribution of patients with acute hepatitis A remained, however, similar over the years (data not shown).

\section{Discussion}


249 were children aged $\leq 10$ years, an age where HAV infection is in the majority asymptomatic 250 (Armstrong \& Bell, 2002). This implies that many more subclinical HAV infections must have 251 occurred in parallel in the population surveyed. Overall, our findings indicate that Nicaragua is

252 still a country of high endemicity and that the single-dose hepatitis A vaccination study

253 (Mayorga et al., 2016) - for which the present project acted as a kind of community control 254 group - had been conducted during a sustained circulation of HAV.

Seroepidemiology: Quantitative anti-HAV IgG antibody levels could only be measured in

256

257

258

259

260

261

262

263

264

265

266

267

268

269

270

271

272

273

274

275

276

277

278

279 263 of the 557 patients with suspected hepatitis. In the Non-A subpopulation tested $(n=94)$, the age-specific seroprotection rates rise until the age of $11-\leq 16$ years, where $100 \%$ seroprotection is reached (Table 2), consistent with the 100\% found from age 18 years onwards in our 2003 study (Mayorga Perez et al., 2014). The present anti-HAV antibody data cannot be used as crosssectional population seroprevalence data, as only symptomatic subjects were screened. However, the data gathered allow the conclusion that hepatitis A is still highly endemic in the area investigated: nine of the 11 Non-A patients lacking seroprotection were $\leq 11$ years of age and only two were 18 and 19 years of age. Nevertheless, the incomplete seroprotection of $71.4 \%$ observed in the age group 16 to $\leq 20$ years, and the fact that two of the five Non-A infants were seronegative, i.e. their mothers most likely as well, indicates the beginning of a transition away from high endemicity. The most recent hepatitis A data cover the years $2004-2012$ and report for the whole country a rise from 19.2 to 36.9 infections per 100,000 inhabitants, and for León a rise from 12.6 to 22.2 (2011), followed by a sharp increase to 86.9/100.000 in 2012

(OPS/PAHO, 2013). Our monthly enrolment of an average 6.7 patients with acute hepatitis A matches well with the average of 6.3 cases reported monthly for León during 2006 - 2010 (OPS/PAHO, 2013). Using our 2003 cross-sectional serosurvey data (Mayorga et al., 2014), a recent literature review on hepatitis A epidemiology in Latin American countries classified the endemicity level of Nicaragua as high-intermediate (Andani et al., 2020), based on the age at midpoint of population immunity (Mohd Hanafiah, Jacobsen \&Wiersma, 2011) of 5 - 9 years. Previous studies in the same area in León showed that there was already between 1995-96 and 2003 a halving of the HAV infection risk for 1 to 5 years old children (Mayorga Perez et al., 2014). Although we found with the limited serosurvey data only few serological indications of shifting endemicity among the non-A cases, i.e. very few HAV susceptible school children or young adults (Table 2), 17.8\% of the acute hepatitis A cases occurred between 10 and $\leq 18$ years 
$280(\mathrm{n}=56)$ and $1.6 \%(\mathrm{n}=5)$ at $>18$ years of age. In addition, there were two cases in infants who are 281 in hyperendemic settings usually seroprotected by maternal antibodies (Brinkhof et al., 2013).

282 Taken all together, these signs of a beginning epidemiological shift are a call for the health 283 authorities to start monitoring hepatitis A more closely, e.g. with repeated cross-sectional 284 serosurveys (Cutts \& Hanson, 2016; Mayorga et al., 2014), in order to not miss the right time to 285 start with public health interventions, such as e.g. universal childhood vaccination.

Clinical features: The clinical outcome of HAV infection is strongly associated with age:

287 below 6 years of age only 10-20\% of infections are symptomatic, at the age of 10 years up to 50 288 $\%$ might present jaundice or other clinical features and from age 18-20 years upwards 80-90\% of 289 infections are symptomatic (Armstrong \& Bell, 2002). The severity of disease and fatal

290 291

292 293 294 295 296 297 298 299 300 301 302 303 304 305 306 307 308 309 310 outcomes are higher in older age groups, with case fatality rising from $0.1 \%$ in children $<15$ years, to $0.3 \%$ among persons $15-39$ years of age and reaching $1.8-5.4 \%$ above 50 years of age (Lemon et al., 2018). In our study, no severe cases were seen, the laboratory findings were 'unspectacular' and corresponded to the overall mild clinical features of the patients enrolled. None of the children or adolescents had to be hospitalized, which is typical for a country where hepatitis A is highly endemic and most infections occur during childhood (WHO, 2010a). However, there are reports from Latin American countries of severe cases with fulminant hepatitis A and acute liver failure (Ciocca et al., 2007; Ferreira et al., 2008), this being an important reason for implementation of UMV of children (Lemon et al., 2018), as e.g. in Argentina (Vizzotti et al., 2014). It is still debated whether differences between various geographic world regions regarding pathogenicity and virulence of HAV are due to genetic host factors in certain ethnic groups or due to nucleotide sequence variations in certain HAV subtypes (Long et al., 2014; Vaughan et al., 2014).

Socioeconomic factors: All over the world the risk of HAV infection is highly correlated with the socioeconomic status (Jacobsen \& Koopman, 2005). Although the global number of HAV infections is still on the rise (WHO, 2012), declining risks of infections are seen in many countries over the last two decades, mainly due to rising sanitary and economic standards and better access to clean water (Jacobsen \& Koopman, 2005), but in some countries also due to UMV, such as in Israel (Levine et al., 2015), Argentina (Vizzotti et al., 2014) and Brazil (Souto, Brito \& Fontes, 2019). This shift from high to intermediate HAV endemicity has been observed in Latin America since the 1990s, a trend which continued in the 2000s (Jacobsen \& Wiersma, 
311 2010; WHO, 2010b; Andani et al., 2020). The risk for HAV infection is influenced by many

312 different factors. Logistic regression analysis showed in Brazil that anti-HAV seroprevalence

313 correlates with increasing age and level of crowding (Vitral et al., 2014), whereas access to clean

314 water and reinforced concrete buildings were protective factors (Vitral et al., 2012). For age and

315 crowding we can see similar effects in our study, with age being the most strongly correlated

316 factor. For the water source we saw no significant effect, even though this is mentioned in many

317 studies from Latin America (Jacobsen \& Wiersma, 2010), probably due to fact that the water was

318 clean in our study area, even if it came from an outside well. In a Brazilian study, an overall low

319 socioeconomic status was identified as risk factor (Vitral et al., 2012). We could not assess this

320 in our study, because we did not evaluate income and education of the families. Thus, the

321 socioeconomic risk factors for HAV identified in our study were only the sanitary conditions, i.e.

322 the place of the toilet, and crowding. Household contacts are an important source of infection

323 (Lima et al., 2014). In our setting, crowding made a significant difference in crude Odds ratios

324 but not in the adjusted ones. Also, we could not see a difference between households hosting 325 different age groups. Another Brazilian study suggests that crowding is confounded by other 326 socioeconomic factors, possibly due to the difficulty in maintaining hygiene in big households

327 (Almeida et al., 2001). In our study this is shown with the adjusted Odds ratio, where the p-value

328 for crowding is no longer significant, indicating that there is a confounding by socioeconomic

329 factors, such as the localization of toilets (Table 3.) In the logistic regression analysis we saw a

330 correlation between the different risk factors. Independently seen, none of the factors made,

331 however, a significant difference. Therefore, the main risk factor appears to be the low

332 socioeconomic status with all his features.

333 Seasonality: In our study there were slightly more hepatitis A cases in the 1st and 4th

334 quarter of the year, i.e. during autumn/winter, when the weather is in Nicaragua slightly cooler

335 and drier. There are seemingly conflicting data published on hepatitis A seasonality, some

336 reports indicating peak incidences in the wet season or summer, as for Brazil (Villar, De Paula \&

337 Gaspar, 2002), others in the dry season or winter, as in Israel (Green et al., 2001). Many different

338 environmental factors, such as rainfall, ambient temperature, and air humidity, as well as host

339 behavior, source of infection and mode of transmission are playing a role in the seasonality of

340 infectious diseases (Martinez, 2018). A recent review on the seasonality of viral hepatitis

341 explains these seemingly conflicting seasonality patterns for hepatitis A infections with the 
342 different modes of transmission being decisive: water-borne during wet summer seasons in case

343 of low hygiene standards and rather food-born in winter, caused e.g. through shellfish

344 consumption (Fares, 2015). Interestingly, even in present-day Spain water-related climate events 345 correlate with the incidence of hepatitis A (Gullón et al., 2017).

$346 \quad$ Our study has limitations: The data collection was done via passive surveillance, relying

347 on self-reporting of cases (parents/patients). The real number of acute hepatitis A cases was most

348 likely higher, as we collected the more symptomatic cases, and because of the low manifestation

349 index in young children, many more asymptomatic HAV infections must have occurred during

350 the observation period. We collected educational levels and jobs only for the enrolled subjects

351 themselves, and not for their mothers/parents, which would have made more sense because most

352 of the patients were young children. Anti-HAV IgG antibody data were only available for $47 \%$

353 of all 557 cases of assumed viral hepatitis and in only 94 of the 242 Non-A cases, limiting the

354 significance of the age-specific seroprotection data, although they pretty well match previous

355 data from the same area (Mayorga Perez et al., 2014). The number of 315 hepatitis A cases was

356 too small to assess in the given setting with certainty the influence of all socioeconomic factors

357 on contracting acute hepatitis A.

358 The strengths of the study were: In a hepatitis A endemic setting, a large series of cases

359 with assumed viral hepatitis was carefully ascertained and laboratory confirmed, allowing to

360 accurately describe the clinical features of hepatitis A. Due to the prospective collection of viral

361 hepatitis cases over all seasons of 4 years, the seasonality features of hepatitis A could be

362 assessed and documented for the first time for Nicaragua. The screening test diagnosis of acute

363 hepatitis A was confirmed by a recognized reference laboratory.

364

365

366

\section{Conclusions}

367

368 Nicaragua is a country of still high hepatitis A endemicity, with all its typical features. The

369 majority of cases were oligosymptomatic with no severe pathology seen in over three hundred

370 documented cases. The main risk factor for acquiring hepatitis $\mathrm{A}$ is living in low socioeconomic

371 conditions. There are some first indications that the endemicity level started in the 2000s shifting 
372 from high to high-intermediate. A closer monitoring of hepatitis $\mathrm{A}$ is warranted in Nicaragua in 373 order to be able to start in time with appropriate public health interventions.

374

375

376

Acknowledgements

377

378

Many thanks go to the staff of the health centers in León, and to the study nurses and laboratory 379 technicians of the Department of Microbiology and Parasitology of the university UNAN in 380 León.

381

382

383

\section{References}

384

385

Almeida LM, Werneck GL, Cairncross S, Coeli CM, Costa MC, Coletty PE. The epidemiology 386 of hepatitis A in Rio de Janeiro: environmental and domestic risk factors. Epidemiology and 387 388

389

Andani A, van Elten TM, Bunge EM, Marano C, Salgado F, Jacobsen KH. Hepatitis A 390

391 epidemiology in Latin American countries: a 2020 view from a systematic literature review.

392

393 Expert Review of Vaccines 2020;19:795-805. DOI: $10.1080 / 14760584.2020 .1813575$ Infection 2001;127:327-33. DOI: $10.1017 / \mathrm{s} 0950268801005945$

Armstrong GL, Bell BP. Hepatitis A virus infections in the United States: model-based estimates 395 and implications for childhood immunization. Pediatrics 2002;109:839-45. DOI:

\subsection{2/peds. 109.5 .839}

396

397

Bell BP, Shapiro CN, Alter MJ, Moyer LA, Judson FN, Mottram K, Fleenor M, Ryder PL, 398 Margolis HS. The diverse patterns of hepatitis A epidemiology in the United States 399 implications for vaccination strategies. Journal of Infectious Diseases 1998; 178:1579-84. DOI:

$400 \quad \underline{10.1086 / 314518}$

401

402

Brinkhof MWG, Mayorga O, Bock J, Heininger U, Herzog C. Kinetics of maternally acquired 
403 anti-hepatitis A antibodies: Prediction of waning based on maternal or cord blood antibody

404 levels. Vaccine 2013;31:1490-5. DOI: 10.1016/j.vaccine.2013.01.011

405

406 Centers for Disease Control and Prevention [CDC]. Prevention of hepatitis A through active or 407 passive immunization: recommendations of the Advisory Committee on Immunization Practices 408 (ACIP). Morbidity and Mortality Weekly Report 2020;69(RR-5):1-38. DOI:

$409 \quad \underline{10.15585 / \text { mmwr.rr6905a1 }}$

416 Cutts FT, Hanson M. Seroepidemiology: an underused tool for designing and monitoring 411 vaccination programmes in low- and middle-income countries. Trop Med Int Health.

412 2016;21(9):1086-98. DOI: $10.1111 / \mathrm{tmi} .12737$

413 Ciocca M, Moreira-Silva SF, Alegría S, Galoppo MC, Ruttiman R, Porta G, Da Silvera TR, 414 Rubio P, Macias M, Cervantes Y, Avila-Agüero ML, Clemens SA, Clemens R, Weil J. Hepatitis 415 A as an etiologic agent of acute liver failure in Latin America. The Pediatric Infectious Disease 416 Journal 2007;26:711-5. DOI: 10.1097/INF.0b013e3180f60bed

Espul C, Cuello H, Lo Castro I, Bravo C, Thollot Y, Voznica J, Vigne C, Coudeville L.

419 Statistical modeling alongside observational data predicts long-term immunogenicity of one dose 420 and two doses of pediatric hepatitis A vaccine in the Mendoza province of Argentina. Vaccine 421 2020;38:1715-22. DOI: $10.1016 /$ j.vaccine.2019.12.049

422

423 Fares A. Seasonality of hepatitis: a review update. Journal of Family Medicine and Primary Care 424 2015;4:96-100. DOI: $\underline{10.4103 / 2249-4863.152263}$

425

426

Ferreira CT, Vieira SMG, Kieling CO, Silveira TR. Hepatitis A acute liver failure: follow-up of 427 paediatric patients in southern Brazil. Journal of Viral Hepatitis 2008;15 (Suppl 2):66-8. DOI: $428 \quad \underline{10.1111 / \mathrm{j} .1365-2893.2008 .01033 . \mathrm{x}}$

429

430 Green MS, Aharonowitz G, Shohat T, Levine R, Anis E, Slater PE. The changing epidemiology 431 of viral hepatitis A in Israel. Israel Medical Association Journal 2001;3:347-51. 
433 Gullón P, Varela C, Martínez EV, Gómez-Barroso D. Association between meteorological

434 factors and hepatitis A in Spain 2010-2014. Environment International 2017;102:230-5. DOI:

$435 \quad \underline{10.1016 / \text { j.envint.2017.03.008 }}$

436

437 Jacobsen K, Koopman JS. The effects of socioeconomic development on worldwide hepatitis A 438 virus seroprevalence patterns. International Journal of Epidemiology 2005;34:600-9. DOI:

$439 \quad \underline{10.1093 / \mathrm{ije} / \mathrm{dyi} 062}$

440

441 Jacobsen KH, Wiersma ST. Hepatitis A virus seroprevalence by age and world region, 1990 and 442 2005. Vaccine 2010;28:6653-7. DOI: 10.1016/j.vaccine.2010.08.037

443

444 Lemon SM, Ott JJ, Van Damme P, Shouval D. Type A viral hepatitis: A summary and update on 445 the molecular virology, epidemiology, pathogenesis and prevention. Journal of Hepatology

446 2018;68:167-84. DOI: 10.1016/j.jhep.2017.08.034

447

448 Levine H, Kopel E, Anis E, Givon-Lavi N, Dagan R. The impact of a national routine 449 immunisation programme initiated in 1999 on hepatitis A incidence in Israel, 1993 to 2012.

450 Eurosurveillance 2015;20:pii=21040. DOI: $\underline{10.2807 / 1560-7917 . e s 2015.20 .7 .21040}$

451

452 Lima LR, De Almeida AJ, dos Santos Tourinho R, Hasselmann B, Lewis Ximenez LL, De Paula 453 VS. Evidence of hepatitis A virus person-to-person transmission in household outbreaks. PLoS 454 One 2014;9:e102925. DOI: 10.1371/journal.pone.0102925

455

Long D, Fix OK, Deng X, Seielstad M, Lauring AS, Acute Liver Failure Study Group. Whole 457 genome sequencing to identify host genetic risk factors for severe outcomes of hepatitis A virus 458 infection. Journal of Medical Virology 2014;86:1661-8. DOI: 10.1002/jmv.24007

459

460

Martinez ME. The calendar of epidemics: seasonal cycles of infectious diseases. PLoS Pathogens 461 2018;14:e1007327. DOI: 10.1371/journal.ppat.1007327

462

Mayorga Perez O, Brinkhof MWG, Egger M, Frösner G, Herzog C, Zwahlen M. Decreasing risk 
464 of hepatitis A infection in León, Nicaragua: Evidence from cross-sectional and longitudinal 465 seroepidemiology studies. PLoS ONE 2014;9:e87643. DOI: 10.1371/journal.pone.0087643 466

467 Mayorga O, Bühler S, Jaeger VK, Bally S, Hatz C, Frösner G, Protzer U, Van Damme P, Egger 468 M, Herzog C. Single-dose hepatitis A immunization: 7.5-year observational pilot study in 469 Nicaraguan children to assess protective effectiveness and humoral immune memory response. 470 Journal of Infectious Diseases 2016;214:1498-506. DOI: 10.1093/infdis/jiw411 471

472 Mohd Hanafiah K, Jacobsen KH, Wiersma ST. Challenges to mapping the health risk of hepatitis 473 A virus infection. International Journal of Health Geographics. 2011;10:57. DOI: 10.1186/1476$474 \quad \underline{072 X-10-57}$

475

476 Organización Panamericana de la Salud [OPS/PAHO] - Nicaragua. Boletin Informativo sobre 477 Hepatitis. Prevención y Control de Enfermedades. Análisis de Salud. Día Mundial contra la 478 Hepatitis [Information bulletin on hepatitis. Prevention and Control of Diseases. Health Analysis. 479 World Day against Hepatitis]. Spanish (31.July 2013). Available from:

480 https://www.paho.org/nic/index.php?option=com docman\&view=document\&category slug=dat 481 os-y-estadisticas\&alias=651-boletin-informativo-sobre-hepatitis\&Itemid=235

482 (accessed 30 December 2020).

483

484

485

486

487

488

489

490

491

492

493

494
Rein DB, Stevens G, Flaxman A, Wittenborn JS, Timothy N, Wiktor SZ, Wiersma ST. The global burden of hepatitis A virus in 1990 and 2005. Journal of Hepatololgy 2014;60:S303.

Souto FJD, Brito WI de, Fontes CJF. Impact of the single-dose universal mass vaccination strategy against hepatitis A in Brazil. Vaccine 2019; 37:771-5. DOI:

$\underline{10.1016 / j . v a c c i n e .2018 .12 .054}$

Talat S, Abid Khan S, Javed N, Iqbal Malik M. Etiology, clinical presentation, and outcome of children with fulminant hepatic failure: Experience from a tertiary center in Pakistan. Pakistan Journal of Medical Sciences 2020;36:1252-6. DOI: 10.12669/pjms.36.6.2375 
495 Urueña A, González JE, Rearte A, Pérez Carrega ME, Calli R, Pagani MF, Uboldi A, Vicentín 496 R, Caglio P, Cañero-Velasco MC, Gentile A, Ramonet M, Vizzoti C. Single-dose universal 497 hepatitis A immunization in one-year-old children in Argentina: High prevalence of protective 498 antibodies up to 9 years after vaccination. The Pediatric Infectious Disease Journal 499 2016;35:1339-42. DOI: 10.1097/INF.0000000000001322

500

501 Vaughan G, Goncalves Rossi LM, Forbi JC, de Paula VS, Purdy MA, Xia G, Khudyakov YE.

502 Hepatitis A virus - Host interactions, molecular epidemiology and evolution. Infection, Genetics 503 and Evolution 2014;21:227-43. DOI: 10.1016/j.meegid.2013.10.023

504

505 Villar LM, De Paula VS, Gaspar AMC. Seasonal variation of hepatitis A virus infection in the 506 city of Rio de Janeiro, Brazil. Revista do Instituto de Medicina Tropical de São Paulo

507 2002;44:289-92. DOI: $\underline{10.1590 / \mathrm{s} 0036-46652002000500011}$

508

509

Vitral CL, Ospina FLN, Artimos S, Melgaço JG, Cruz OG, de Paula VS, Luz SB, Freire M, 510 Gaspar LP, Amado LA, Engstrom EM, Fortes CD, Souza TC, Dias MN, Gaspar AM, Souto FJ.

511 Declining prevalence of hepatitis A virus antibodies among children from low socioeconomic 512 groups reinforces the need for the implementation of hepatitis A vaccination in Brazil. Memórias 513 do Instituto Oswaldo Cruz 2012;107:652-8. DOI: 10.1590/s0074-02762012000500012

514

515 Vitral CL, da Siulva-Nunes M, Pinto MA, de Oliveira JM, Gaspar AM, Pereira RC, Ferreira MU. 516 Hepatitis A and E seroprevalence and associated risk factors/ a community-based cross-sectional 517 survey in rural Amazonia. BMC Infectious Diseases 2014;14:458. DOI: 10.1186/1471-2334-14$518 \underline{458}$

519

520 Vizzotti C, González J, Gentile A, Rearte A, Ramonet M, Cañero-Velasco MC, Pérez Carrega 521 ME, Urueña A, Diosque M. Impact of the single-dose immunization strategy against hepatitis A 522 in Argentina. The Pediatric Infectious Disease Journal 2014;33:84-8. DOI:

$523 \quad \underline{10.1097 / \text { INF.0000000000000042 }}$

524

525 World Health Organization: The Immunological Basis for Immunization Series. Module 18: 
526 Hepatitis A. Geneva, WHO, 2010a. Available at:

527 http://whqlibdoc.who.int/publications/2011/9789241501422 eng.pdf. (accessed 30 November 528 2020)

529

530 World Health Organization. The Global Prevalence of Hepatitis A Virus Infection and

531 Susceptibility: A Systematic Review. World Health Organization (2010b). WHO/IVB/10.01.

532 Available at: https://apps.who.int/iris/handle/10665/70180 (accessed 30 November 2020).

533

534 World Health Organisation. WHO position paper on hepatitis A vaccines - June 2012. Weekly 535 Epidemiological Record 2012;87:261-76.

536

537 


\section{Table 1 (on next page)}

Characteristics of study population

*cut-off definitions are described in the method section 
1 Table 1: Characteristics of study population

2

\begin{tabular}{|c|c|c|c|c|}
\hline \multirow[t]{2}{*}{ Characteristic } & \multirow[t]{2}{*}{ Category } & \multicolumn{2}{|c|}{$\mathbf{N}(\%)$} & \multirow[t]{2}{*}{ p-value } \\
\hline & & $\begin{array}{c}\text { Acute Hepatitis A } \\
(\mathrm{n}=315)\end{array}$ & $\begin{array}{c}\text { Non Hepatitis A } \\
(\mathrm{n}=242)\end{array}$ & \\
\hline \multicolumn{5}{|l|}{ Demographics } \\
\hline \multirow[t]{7}{*}{ Age } & & & & $<0.001$ \\
\hline & $\leq 1$ year & $2(0.6)$ & $16(6.6)$ & \\
\hline & $1-\leq 5$ years & $70(22.2)$ & $47(19.4)$ & \\
\hline & $5-\leq 10$ years & $182(57.8)$ & 64 (26.4) & \\
\hline & $10-\leq 14$ years & $46(14.6)$ & $32(13.2)$ & \\
\hline & $14-\leq 18$ years & $10(3.2)$ & $11(4.5)$ & \\
\hline & $>18$ years & $5(1.6)$ & $72(29.8)$ & \\
\hline \multirow[t]{3}{*}{ Sex } & & & & 1.000 \\
\hline & female & $157(49.8)$ & $120(49.6)$ & \\
\hline & male & $158(50.2)$ & $122(50.4)$ & \\
\hline \multicolumn{5}{|l|}{ Socioeconomic } \\
\hline \multirow[t]{3}{*}{ Housing } & & & & 0.013 \\
\hline & no crowding & $141(44.8)$ & $135(55.8)$ & \\
\hline & crowding & $174(55.2)$ & $107(44.2)$ & \\
\hline \multirow[t]{3}{*}{ Toilets } & & & & 1.000 \\
\hline & outside & $157(49.8)$ & $99(40.9)$ & \\
\hline & inside & $158(50.2)$ & $143(59.1)$ & \\
\hline \multirow{3}{*}{ Water } & & & & 0.044 \\
\hline & outside & $57(18.1)$ & $43(17.8)$ & \\
\hline & inside & $258(81.9)$ & $199(82.2)$ & \\
\hline \multicolumn{5}{|l|}{ Clinical features } \\
\hline \multirow[t]{3}{*}{ Jaundice } & & & & $<0.001$ \\
\hline & no & $14(4.4)$ & $48(19.8)$ & \\
\hline & yes & 301 (95.6) & $194(80.2)$ & \\
\hline \multirow[t]{3}{*}{ Pale stool } & & & & $<0.001$ \\
\hline & no & $207(65.7)$ & $203(83.9)$ & \\
\hline & yes & $108(34.3)$ & $39(16.1)$ & \\
\hline \multirow[t]{3}{*}{ Dark urine } & & & & $<0.001$ \\
\hline & no & $120(38.1)$ & $162(66.9)$ & \\
\hline & yes & $195(61.9)$ & $80(33.1)$ & \\
\hline \multirow[t]{3}{*}{ Nausea } & & & & $<0.001$ \\
\hline & no & $83(26.3)$ & $98(40.5)$ & \\
\hline & yes & $232(73.7)$ & $144(59.5)$ & \\
\hline \multirow[t]{3}{*}{ Vomiting } & & & & 0.001 \\
\hline & no & $81(25.7)$ & $127(52.5)$ & \\
\hline & yes & $234(74.3)$ & $115(47.5)$ & \\
\hline \multirow[t]{3}{*}{ Fever } & & & & 0.014 \\
\hline & no & $64(20.3)$ & $72(29.8)$ & \\
\hline & yes & $251(79.7)$ & $170(70.2)$ & \\
\hline \multirow[t]{3}{*}{ Anorexic } & & & & 0.004 \\
\hline & no & $55(17.5)$ & $68(28.1)$ & \\
\hline & yes & $260(82.5)$ & $174(71.9)$ & \\
\hline Malaise & & & & 0.101 \\
\hline & no & $46(14.6)$ & $49(20.2)$ & \\
\hline & yes & $269(85.4)$ & $193(79.8)$ & \\
\hline Laboratory finding* & & & & \\
\hline Liver enzymes GOT & & & & $<0.001$ \\
\hline & elevated & $281(89.2)$ & $108(44.6)$ & \\
\hline & normal & $34(10.8)$ & $134(55.4)$ & \\
\hline Liver enzymes GTP & & & & $<0.001$ \\
\hline & elevated & $289(91.7)$ & $93(38.4)$ & \\
\hline & normal & $26(8.3)$ & $149(61.6)$ & \\
\hline
\end{tabular}




\begin{tabular}{lllll}
\hline \multirow{2}{*}{ Characteristic } & Category & \multicolumn{2}{c}{$\mathbf{N}(\%)$} & p-value \\
\cline { 3 - 4 } & & \multicolumn{1}{c}{$\begin{array}{c}\text { Acute Hepatitis A } \\
(\mathrm{n}=315)\end{array}$} & $\begin{array}{c}\text { Non Hepatitis A } \\
(\mathrm{n}=242)\end{array}$ & \\
\hline Total serum bilirubin & & & $118(48.8)$ & $<0.001$ \\
& elevated & $274(87.0)$ & $124(51.2)$ & \\
\hline
\end{tabular}

*cut-off definitions are described in the method section 


\section{Table 2 (on next page)}

Anti-HAV IgG antibody levels of subgroup of patients $(n=94)$ without hepatitis A

GMC: geometric mean concentration; $\mathrm{Cl}$ : confidence interval

* For $<10 \mathrm{mlU} / \mathrm{ml}$ a value of $5 \mathrm{mIU} / \mathrm{ml}$ was used for the $\mathrm{GMC}$ calculation

** Seroprotection: $\geq 20 \mathrm{mlU} / \mathrm{mL}$ of anti-HAV IgG antibodies 
1

2 Table 2: Anti-HAV IgG antibody levels of subgroup of patients $(n=94)$ without hepatitis A 3

\begin{tabular}{|c|c|c|c|c|}
\hline \multicolumn{2}{|c|}{ Patients tested } & \multicolumn{2}{|c|}{$\begin{array}{l}\text { Anti-HAV IgG antibody concentrations } \\
\qquad(\mathrm{mIU} / \mathrm{mL})\end{array}$} & \multirow{2}{*}{$\begin{array}{c}\text { Seroprotection** } \\
n(\%)\end{array}$} \\
\hline $\mathrm{n}=94$ & & $\mathrm{GMC}^{*}(95 \% \mathrm{CI})$ & $\operatorname{Min} / \max$ & \\
\hline \multicolumn{5}{|l|}{ Age } \\
\hline$\leq 1$ year & 5 & $106.3(2.4 ; 4,719.9)$ & $<10 / 6,173$ & $3(60.0)$ \\
\hline $1-\leq 6$ years & 16 & $965.6(111.7 ; 8,345.2)$ & $<10 / 209,900$ & $11(68.8)$ \\
\hline $6-\leq 11$ years & 19 & $8,267.6(1,889.9 ; 36,167.4)$ & $<10 / 147,100$ & $17(89.5)$ \\
\hline $11-\leq 16$ years & 13 & $10,568.9(5,178.7 ; 21,569.4)$ & $989 / 50,380$ & $13(100.0)$ \\
\hline $16-\leq 20$ years & 7 & $1,004.6(30.8 ; 32,751.5)$ & $<10 / 32,300$ & $5(71.4)$ \\
\hline $20-\leq 25$ years & 9 & $11,990.0(6,557.8 ; 21,921.8)$ & $3,529 / 29,050$ & $9(100.0)$ \\
\hline$>25$ years & 25 & $5,487.8(3,468.7 ; 8,682.1)$ & $602 / 34,150$ & $25(100.0)$ \\
\hline \multicolumn{5}{|c|}{ GMC: geometric mean concentration; CI: confidence interval } \\
\hline \multicolumn{5}{|c|}{ * For $<10 \mathrm{mIU} / \mathrm{ml}$ a value of $5 \mathrm{mIU} / \mathrm{ml}$ was used for the GMC calculation } \\
\hline \multicolumn{5}{|c|}{ ** Seroprotection: $\geq 20 \mathrm{mIU} / \mathrm{mL}$ of anti-HAV IgG antibodies } \\
\hline
\end{tabular}




\section{Table 3 (on next page)}

Hepatitis A: Sociodemographic factors, multiple logistic regression

$\mathrm{N}$ : patients enrolled with suspected viral hepatitis; $n$ : patients with acute hepatitis $A$; OR:

Odds Ratio; $\mathrm{Cl}$ : confidence interval; ref = reference group; *Adjusted for: sex, age, housing, toilets and water; ${ }^{* *}$ crowding defined as $>2.5$ persons/room; $* * *$ toilet outside $=$ outside or latrine; $* * * *$ water outside $=$ water from a well 
2 Table 3: Sociodemographic factors, multiple logistic regression

\begin{tabular}{|c|c|c|c|c|c|c|}
\hline Characteristics & $\begin{array}{l}\text { Total } \\
\mathrm{N}\end{array}$ & $\begin{array}{c}\text { Hepatitis A patients } \\
\mathrm{n}(\% \text { of } \mathrm{N})\end{array}$ & $\begin{array}{l}\text { Crude OR } \\
(95 \% \mathrm{CI})\end{array}$ & $\begin{array}{l}\text { Adjusted OR* } \\
\quad(95 \% \mathrm{CI})\end{array}$ & $\begin{array}{l}\text { P- value } \\
\text { (crude) }\end{array}$ & $\begin{array}{c}\text { P-value } \\
\text { (adjusted } \\
\text { ) }\end{array}$ \\
\hline & 557 & $315(56.6)$ & & & & \\
\hline \multicolumn{7}{|l|}{ Sex } \\
\hline Female & 277 & $157(56.7)$ & $1.0(\mathrm{ref})$ & $1.0(\mathrm{ref})$ & & \\
\hline Male & 280 & $158(56.4)$ & $0.99(0.71-1.38)$ & $0.97(0.66-1.42)$ & 0.953 & 0.872 \\
\hline \multicolumn{7}{|l|}{ Age } \\
\hline $0-\leq 5$ years & 135 & $72(53.3)$ & 1.0 (ref) & $1.0($ ref $)$ & & \\
\hline $5-\leq 10$ years & 246 & $182(74.0)$ & $2.49(1.6-3.88)$ & $2.45(1.57-3.84)$ & & \\
\hline $10-\leq 14$ years & 78 & $46(59.0)$ & $1.26(0.72-2.22)$ & $1.27(0.72-2.25)$ & & \\
\hline $14-\leq 18$ years & 21 & $10(47.6)$ & $0.8(0.31-2.01)$ & $0.8(0.31-2.04)$ & & \\
\hline$>18$ years & 77 & $5(6.5)$ & $0.06(0.02-0.15)$ & $0.063(0.02-0.15)$ & $<0.001$ & $<0.001$ \\
\hline \multicolumn{7}{|l|}{ Housing } \\
\hline No crowding** & 276 & $141(51.1)$ & 1.0 (ref) & 1.0 (ref) & & \\
\hline Crowding & 281 & 174 (61.9) & $1.56(1.11-2.18)$ & $1.1(0.75-1.62)$ & 0.01 & 0.62 \\
\hline \multicolumn{7}{|l|}{ Toilets } \\
\hline Outside*** & 256 & $157(61.3)$ & $1.0(\mathrm{ref})$ & 1.0 (ref) & & \\
\hline Inside & 301 & $158(52.5)$ & $0.7(0.5-0.98)$ & $0.75(0.48-1.15)$ & 0.036 & 0.191 \\
\hline \multicolumn{7}{|l|}{ Water } \\
\hline Outside $* * * *$ & 100 & $57(57.0)$ & 1.0 (ref) & $1.0(\mathrm{ref})$ & & \\
\hline Inside & 457 & $258(56.5)$ & $0.98(0.63-1.51)$ & $1.41(0.82-2.42)$ & 0.921 & 0.209 \\
\hline
\end{tabular}


$5 \mathrm{~N}$ : patients enrolled with suspected viral hepatitis; n: patients with acute hepatitis A; OR: Odds Ratio; CI: confidence interval; ref = 6 reference group

7 *Adjusted for: sex, age, housing, toilets and water; $* *$ crowding defined as $>2.5$ persons/room; $* * *$ toilet outside $=$ outside or latrine; $8 * * * *$ water outside $=$ water from a well 
Figure 1

Study flowchart 


\section{Patients screened for} suspected viral hepatitis

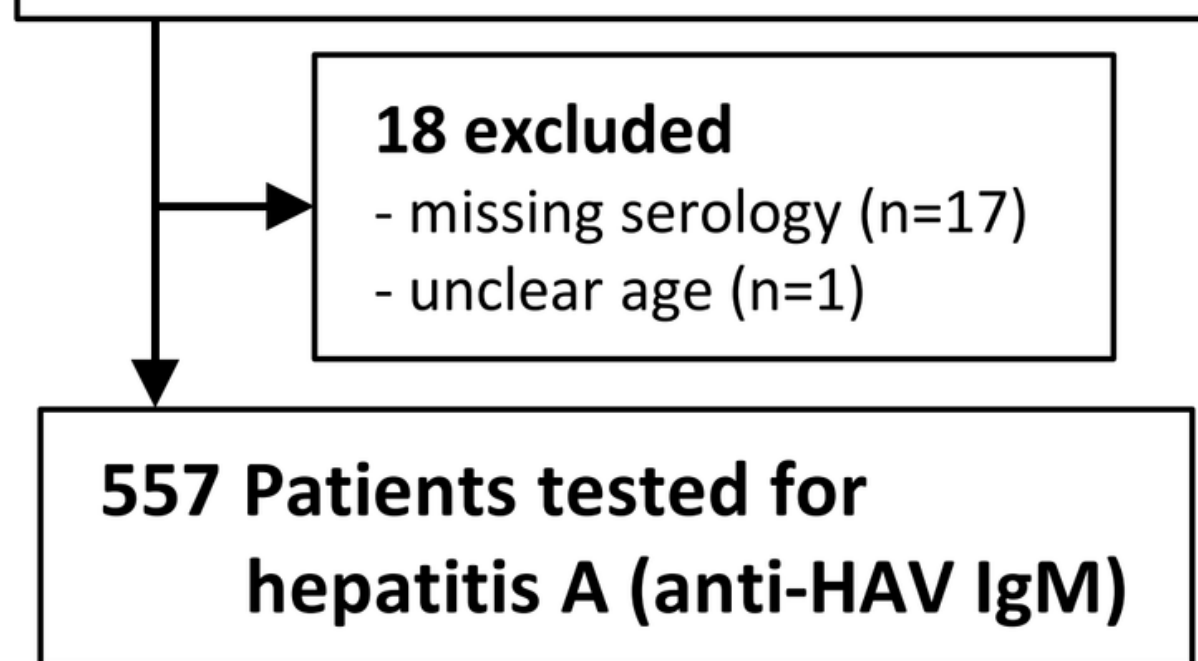

315 Acute hepatitis A (anti-HAV IgM pos.)

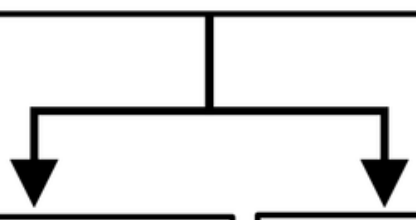

242 Non-hepatitis A (anti-HAV IgM neg.)

\section{Anti-HAV IgG test \\ - seropositive $(n=166)$ \\ - seronegative $(n=0)$ \\ - no measurements available $(n=149)$}

Anti-HAV IgG test

- seropositive $(n=83)$

- seronegative $(n=11)$

- no measurements available $(n=148)$ 
Figure 2

City of León: Seasonality of symptomatic hepatitis A cases 2006 - 2010

Monthly numbers of enrolled symptomatic hepatitis A cases by years (2006 - 2010); thick gray line represents median number of cases per month

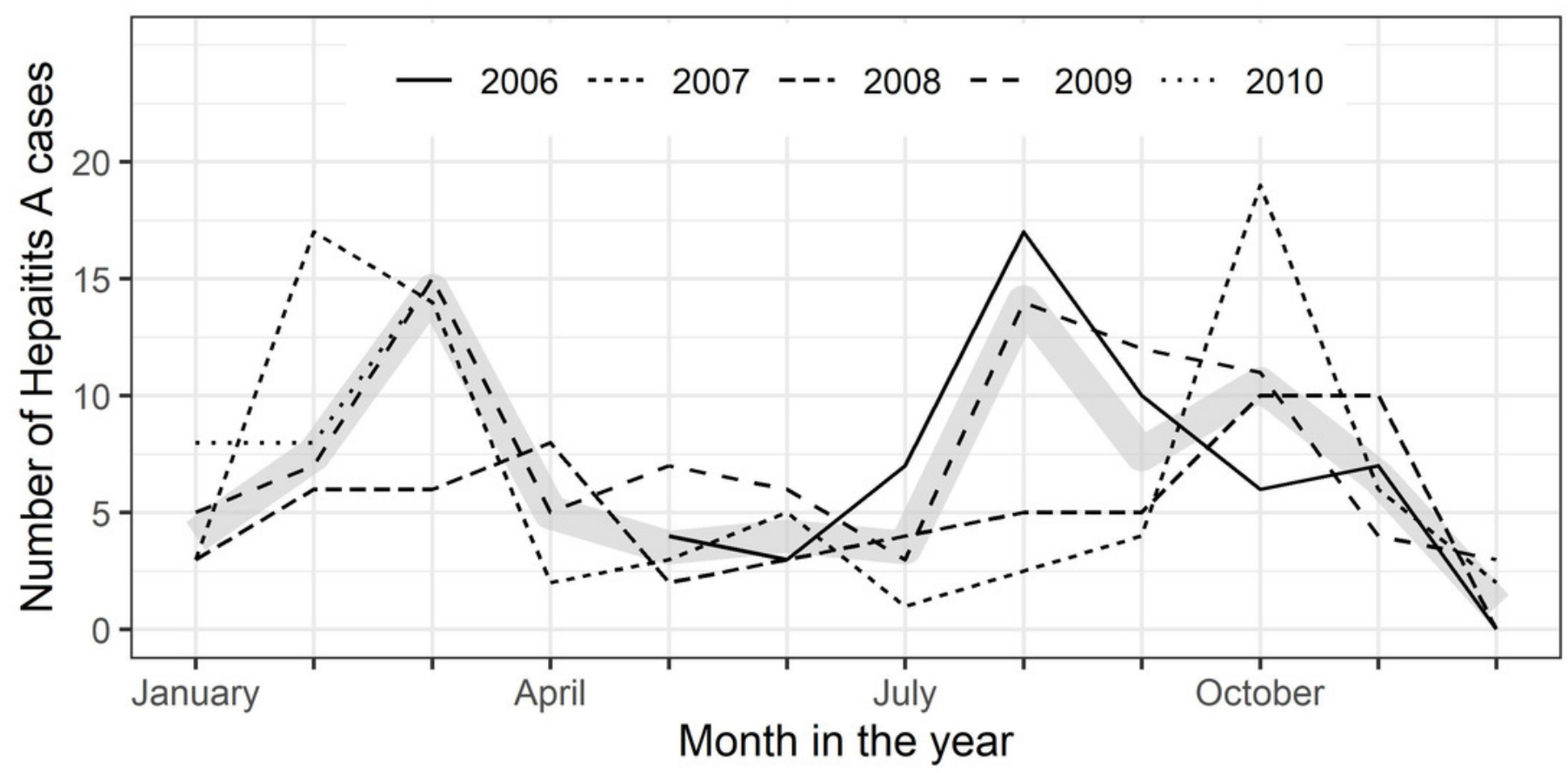

